\title{
Daria Nowicka
}

Uniwersytet im. Adama Mickiewicza w Poznaniu

iD http://orcid.org/0000-0002-6315-7588

\section{Rewizja/e - Andrzeja Wróblewskiego rozpamiętywanie przeszłości*}

\section{Revision(s) - Andrzej Wróblewski's Dwelling on the Past}

\begin{abstract}
This article is an interpretation of the work of art entitled Revision Arrest, painted in 1953. The first part of the text describes research on trauma and class of narrative related to it. Next, the text discusses the influence of the experience of war - and the death of his father - on the development of Wróblewski's subsequent decisions regarding art, life, and aesthetics. The analysis connects the study of individual aspects of the image with the war-visions of the artist, with the goal of identifying points of correspondence between history and the work.
\end{abstract}

Key words: Andrzej Wróblewski, polish painting, executions, memory, trauma

Streszczenie: Niniejszy artykuł poświęcony jest interpretacji obrazu Rewizja Aresztowanie, powstałemu w 1953 roku. Pierwsza część tekstu dotyczy badań nad traumą i związaną z nią kategorią narracji. Kolejna porusza problem wpływu przeżycia wojennego - śmierci ojca - na kształt sztuki Andrzeja Wróblewskiego, na jego późniejsze decyzje życiowe, artystyczne, estetyczne. Analizy poszczególnych partii obrazu autorka łączy również z imaginacjami wojennymi artysty, poszukując korespondencji między historią a dziełem.

Słowa kluczowe: Andrzej Wróblewski, malarstwo polskie, rozstrzelania, pamięć, trauma

* Niniejszy tekst jest częścią badań doktorskich, jakie poświęcam konstelacjom poetyckim Andrzeja Wróblewskiego. 
Jednym z decydujących momentów w biografii Andrzeja Wróblewskiego był widok jego ojca Bronisława, umierającego podczas rewizji wileńskiego mieszkania ${ }^{1}$. Współuczestniczenie czternastoletniego wówczas chłopca w tym zdarzeniu być może wpłynęło na podejmowaną później przez malarza tematykę jego prac - obrazy, poprzez które starał się oddać wielokierunkowe i wieloznaczne doświadczenie cierpienia czy samotności.

Owo dramatyczne wydarzenie, w perspektywie humanistycznej, pozostaje $\mathrm{w}$ pewnym stopniu interwencyjne. Zestawienie płócien artysty z późniejszymi interpretacjami jego prac, autorstwa m.in.: Jana Michalskiego, Magdaleny Ziółkowskiej czy Doroty Jareckiej, pozwala zastanowić się nad tożsamością Wróblewskiego, określić, w jakim stopniu można mówić o doświadczeniu przez niego traumy dzieciństwa ${ }^{2}$. Taką sferą domysłów pozostaje również semantyka, jak i imaginacja $w$ jego obrazach. $W$ poczynionych już przez badaczy interpretacjach zastanawia jednak nikłe określenie tożsamości artysty bezpośrednio tuż po tragicznym wydarzeniu: zbyt słabe odróżnienie chłopca od chłopaka, w którego zmienia się artysta, analizy jego późniejszych obrazów właśnie w kontekście tragedii rodzinnej. Wydawać by się mogło, że chłopcem Wróblewski był do momentu śmierci ojca, wychowywany w atmosferze sztuki i wyka-

1 „Po wybuchu wojny [Andrzej Wróblewski - D.N.] kontynuuje naukę na tajnych kompletach. W roku $1941 \mathrm{w}$ czasie rewizji wojsk sowieckich w mieszkaniu Wróblewskich umiera na skutek apopleksji, na oczach syna, ojciec Andrzeja". Por. Andrzej Wróblewski nieznany. Red. J. Michalski. Kraków 1993, s. 262. W poszczególnych zapisach odnośnie do wileńskiego wydarzenia pojawiają się różnice w określeniu narodowości wojsk wkraczających do mieszkania Wróblewskich.

2 Por. Unikanie stanów pośrednich. Andrzej Wróblewski (1927-1957). Red. M. ZıóŁкowska, W. GrzybaŁa. Warszawa 2014; Andrzej Wróblewski nieznany...; J. Michalski: Chłopiec na żółtym tle. Teksty o Andrzeju Wróblewskim. Kraków 2009; D. JARECKA: Wewnętrzne organy kontroli. W: Ciała zdruzgotane, ciała oporne. Afektywne lektury XX wieku. Red. A. Lipszyc, M. ZALEski. Warszawa 2015, s. 128-147. Na zapis Marty Tarabuły dotyczący wileńskiego doświadczenia artysty zwracałam uwagę w artykule: "Styszę was głosy zabitych" - Andrzeja Wróblewskiego przypis do Louisa Aragona. „Narracje o Zagładzie” 2019, nr 5, s. 176-198. Tematykę śmierci jako motyw powtórzenia omawiałam również w następujących tekstach: Artysta i mit. Wokót „Treści uczuciowej rewolucji” Andrzeja Wróblewskiego. „Porównania" 2018, T. 23, nr 2, s. 259-278; Błękitne, wewnętrzne [...] sa w wołaniu. Im-pasywne obrazy w poezji Juliana Kornhausera [Od Wróblewskiego: Niebo nad górami]. W: Rzeczy do nazwania. Wokót Kornhausera. Red. A. Gleń, J. Kornhauser. Poznań, s. 470-482; Zasypia ryba. Autobiograficzne i zwierzęce niepokojenia w malarstwie Andrzeja Wróblewskiego. „Narracje o Zagładzie” 2017, nr 3, s. 217-232. 
zujący początkowe artystyczne zdolności. Z tego okresu pochodzą pierwsze, dziecięce rysunki Andrzeja, który na marginesach swoich prac dedykuje je głównie matce: „dla pocieszenia Mamy”, „Mamo, nie gniewaj się”, „Niech żyje Mama”" się bezpośrednio w czasie uczęszczania do Szkoły Powszechnej w Wilnie, gdzie, jako uczeń, Wróblewski maluje okazjonalne laurki, a także dedykuje matce $\mathrm{z}$ okazji jej imienin lub świąt własnoręcznie zaprojektowane książki. Pojawiają się jednak już w tym okresie pewne komplikacje. Artysta nie wspomina o swojej relacji z ojcem, który przed śmiercią jawi mu się jako postać niemal widmowa, nieobecna w jego życiu. Może więc ta dominująca i najbliższa relacja artysty z matką wynikała z silnego domowego matriarchatu, może dlatego malarz nie wyrażał pustki bezpośrednio po stracie jednego $\mathrm{z}$ rodziców.

A jednak późniejsze obrazy Wróblewskiego, w których pojawia się on jako dojrzały mężczyzna, każą widzieć w postaci artysty zbuntowanego chłopaka, rezygnującego z głębokiej relacji z matką. Nie tyle więc chodziłoby tu o prostą zależność dystansowania się dorosłego syna wobec rodziców, nie tyle o młodzieżowy bunt, ile o tożsamościowy zwrot Wróblewskiego w stronę nieobecnego ojca. W świetle tych zmian uważnie należy przyjrzeć się obrazom opartym na wizualnej metaforze dzieciństwa, spróbować dostrzec w nich tożsamościowe zmiany, jakie zachodziły w psychice młodego Wróblewskiego. Pamiętać jednak należy o tym, że postać chłopca powraca w najbardziej dramatycznych obrazach artysty.

Niniejszy artykuł poświęcony jest interpretacji obrazu Rewizja Aresztowanie (zapis tytułu podaję za monografią pt. Unikanie stanów pośrednich), powstałemu w latach 1952-1953. W tym przedstawieniu doszukuję się źródeł sytuacji granicznej w biografii Wróblewskiego. W pierwszej części tekstu odwołuję się więc do badań nad traumą i związaną z nią kategorią narracji. Sygnalizuję doświadczenie przeżycia wojennego - śmierci ojca, która mogła mieć znaczący wpływ na kształt sztuki artysty oraz na jego późniejsze decyzje życiowe. W następnych częściach analizuję poszczególne sekcje obrazu, zestawiając je z dotychczasowymi badaniami twórczości Wróblewskiego, dotyczącymi problematyki obrazów wojny, studiami nad pamięcią i językiem artystycznym. Część tekstu poświęcam również analizie samotności Wróblewskiego będącej konsekwencją traumatycznego przeżycia artysty. Interesującym kontekstem dla prowadzonych

${ }^{3}$ Kronika wydarzeń. Andrzej Wróblewski kraj. Oprac. M. TarabuŁa. W: Andrzej Wróblewski nieznany..., s. 262. 
analiz mogą okazać się również imaginacje wojenne Andrzeja Wróblewskiego, zawarte m.in. w takich obrazach, jak: Szofer, Kolejka trwa, Ukrzesłowienie czy też w cyklu Rozstrzelań, które czytam zgodnie $\mathrm{z}$ kategorią autotanatografii ${ }^{4}$.

\section{Wokół realizmu traumatycznego}

W Modi memorandi. Leksykonie kultury pamięci autorka hasła „trauma” - Katarzyna Bojarska - zaznaczyła cztery główne osie problemowe, wokół których zdefiniowała owo pojęcie. Są to: historia traumy, związek traumy i narracji, kultura posttraumatyczna oraz traumy kulturowe i społeczne. Badaczka na początku zwróciła uwagę na etymologię samego słowa, pochodzącego z języka greckiego, a dokładniej z rejestru medycznego, gdzie trauma oznaczała pierwotnie: ranę, uraz. Tak rozumiany leksem został przeniesiony z języka medycznego najpierw do psychiatrii, a następnie do teorii kultury i nauk społecznych, stając się $\mathrm{w}$ ten sposób jedną z najbardziej popularnych kategorii badawczych, o czym świadczą analizy ostatnich lat:

Trauma pojawia się $\mathrm{w}$ następstwie zdarzenia odznaczającego się szczególną intensywnością. Ten, kto jej doświadcza, staje się niezdolny do jej przyswojenia i adekwatnej reakcji na nią. Oznacza ona wstrząs i jego patogenne skutki dla psychiki jednostki, a w ujęciu zbiorowym - dla organizacji społeczności. Traumę charakteryzuje nadmierna liczba niemożliwych do opanowania bodźców: nie sposób ich psychicznie opracować ani włączyć w porządek reprezentacji i rozumienia. Jest to przeżycie, które w krótkim czasie silnie pobudza psychikę. Nie można się go pozbyć ani przyswoić za pomocą dostępnych środków i procedur. To gwałtowne i szokowe rozbicie jedności, wyrwa, pęknięcie 5 .

4 Aleksandra Ubertowska w książce Holokaust. Auto(tanato)grafie (Warszawa 2014), wykorzystuje badania zachodnioeuropejskie, w tym przede wszystkim badania Jacques'a Derridy do opisu różnogatunkowych tekstów poświęconych Zagładzie. Badaczka przekształca Derridiańską formułę autobio-tanatografii w auto(tanato)grafie. Kategoria ta została później przejęta przez Wojciecha SzYMAŃSKIEGo. Por. IDEM: „Obraz tym się różni od pilnika, że jest w użyciu wszechstronniejszy" lub Andrzej Wróblewski na nowo odczytany: notatki na marginesie „Unikania stanów pośrednich”. „Sztuka i Dokumentacja” 2014, nr 11, s. 115-124.

${ }^{5}$ K. Bojarska: Trauma. W: Modi memorandi. Leksykon kultury pamięci. Red. M. Saryusz-Wolska, R. Traba. Warszawa 2014, s. 501. 
Historia traumy sięga XIX wieku, tekstów Johna Erichsena, Jeana-Martina Charcota i Pierre'a Janeta. Początkowo uważano ją za chorobę pamięci. Było to spowodowane objawiającymi się urazami, relacją między świadomością i nieświadomością, a także pogłębiającymi się mechanizmami wyparcia, chroniącymi przed powtórnym zranieniem. Ważnym momentem dla badań nad traumą było wyjście poza dyskurs medyczny oraz rozszerzenie jej znaczenia o opowieść historyczną. Freud odniósł traumę do swoistego kryzysu reprezentacji. Według badacza nie wytwarzała ona wspomnień, ale je aktualizowała. Jeszcze silniej nazwał to zjawisko Lacan w swoim wystąpieniu na XI seminarium, zwracając uwagę, iż trauma wiąże się z powtórzeniem, powtórzeniem pamięci. Jedynie $\mathrm{w}$ retrospekcji można ją nazwać, nadać jej sens, tylko w taki sposób podmiot uwikłany w nią może zrozumieć i zobaczyć minione doświadczenie jako spójne.

Katarzyna Bojarska zauważa, że

$\mathrm{z}$ inspiracji myślą Lacanowską $\mathrm{w}$ dyskursie teoretycznym, ale $\mathrm{i}$ artystycznym nastąpiło znaczące przesunięcie $\mathrm{w}$ rozumieniu Realnego: z efektu reprezentacji stał się on wydarzeniem traumy. Ujmowali to przekonująco $\mathrm{w}$ swoich koncepcjach realizmu traumatycznego Michael Rothberg (w kontekście narracji o historycznej traumie Zagłady) i Hal Foster (w kontekście sztuki Andy'ego Warhola [1927-1987]) $)^{6}$.

Foster, analizując cykl Śmierć w Ameryce Warhola, postulował oparcie się na realizmie traumatycznym. Krytycznie odniósł się do lektury Lacana, mówiąc, iż „powtarzanie nie jest reprodukcją" ${ }^{7}$, jego zdaniem istotna jest rola punctum jako źródła traumatycznego miejsca. Istoty traumy upatrywał w mieszaniu się „wnętrza" i „zewnętrza”, „powtórzenie służy raczej zasłonięciu Realnego pojmowanego jako traumatyczne"

Noit Banai, badaczka twórczości autora Rozstrzelań, zauważyła jednak, że rozważania Fostera, odnoszące się do sztuki masowej USA, niekoniecznie znajdują pokrycie $\mathrm{w}$ pracach Wróblewskiego. Pomocna okazała się tu teoria traumy w opracowaniu Michaela

\footnotetext{
${ }^{6}$ Ibidem, s. 502.

${ }^{7}$ H. Foster: Powrót Realnego. Awangarda u schyłku XX wieku. Przeł. M. BorowSKI, M. Sugiera. Kraków 2012, s. 160.

${ }^{8}$ N. Banar: Figuracja eksperymentalna w stanie wyjątkowym. W: Unikanie stanów pośrednich. Andrzej Wróblewski (1927-1957)..., s. 229.
} 
Rothberga, znosząca różnicę między realnym a traumatycznym. Badaczka uważała, przeciwnie do Fostera, że należy rozszerzyć samo miejsce traumy - pokazać „kontrasty między tym, co codzienne, i tym, co krańcowe, czyli traumatyczne" ${ }^{\prime \prime}$.

W przypadku Andrzeja Wróblewskiego kwestia traumy wydaje się dość skomplikowana. Z jednej strony, zaproponowane powyżej koncepcje jej rozumienia i ich transpozycje można bezpośrednio odnieść do biografii i twórczości artysty. Świadczą o tym graniczne doświadczenie, mechanizmy wyparcia czy kamuflowanie traumy przez artystę $\mathrm{w}$ dorosłym życiu. $Z$ drugiej jednak strony - istotna wydaje się również materialność obrazów, to, że malarz zdawał się swoimi pracami "traumatyzować” ówczesną rzeczywistość w podobnym stopniu jak rzeczywistość traumatyzowała jego sztukę.

Zaproponowana przez Rothberga koncepcja realizmu traumatycznego znalazła zastosowanie $w$ badaniach nad eksperymentalną figuracją w obrazach Wróblewskiego. Banai łączyła realizm traumatyczny z estetycznym zapisem suwerenności artysty, rozumiała go w następujący sposób:

Większość źródeł dotyczących życia Wróblewskiego wspomina o przerażającym zdarzeniu z okresu wojny, kiedy jako czternastoletni chłopiec był on świadkiem śmierci swojego ojca, który zmarł na atak serca podczas rewizji domu rodzinnego przeprowadzonej przez nazistów w Wilnie (26 VIII 1941). Nie umniejszając wagi tego doświadczenia dla samego artysty, należy stwierdzić, że podobne, choć z dzisiejszej perspektywy niewyobrażalne, zdarzenia, nie były wówczas czymś wyjątkowym i wywarły wpływ zarówno na Wróblewskiego, jak i wiele innych osób z jego pokolenia. Tak więc, pamiętając o aspekcie biograficznym, współtworzone przez Rozstrzelania estetyczne znaczenia wymagają szerszego spojrzenia, $\mathrm{w}$ ramach którego cele i problemy realizmu traumatycznego jawią się jako malarska odpowiedź na bieg historii. [...] Przede wszystkim chodzi o ograniczenia reprezentacji (obrazowania) w kwestii uchwycenia (nie wspominając już o przekazywaniu) stanu wyjątkowego - skutku nowego paradygmatu przemocy totalnej Trzeciej Rzeszy. Na poziomie najbardziej podstawowym należy zapytać, czy ową rzeczywistość zinstrumentalizowanej śmierci można w ogóle poznać? Czy konstelacja zdarzeń, które zwykło się określać barbarzyńskimi zbrodniami przeciwko ludzkości - staranna organizacja gett, łapanek, transportów, rozstrzelań, obozów pracy i obozów zagłady - może zostać zrozumiana? ${ }^{10}$

\footnotetext{
9 Ibidem, s. 230.

${ }^{10}$ Ibidem, s. 226.
} 
Nieco dalej Banai doprecyzowuje, na czym w twórczości Wróblewskiego miałby polegać ów realizm traumatyczny:

Zniuansowane i złożone spojrzenie Rothberga na realizm traumatyczny jest istotnym krokiem do zrozumienia Rozstrzelań. Niemniej jednak pełna pasji konfrontacja Wróblewskiego z zagadnieniem wojny wymaga również specyficznego podejścia do ciała - zarówno jako miejsca traumy, jak i struktury wizualnej pozwalającej na inną formę suwerenności, suwerenności politycznej i tej dotyczącej podmiotu. [...] W Rozstrzelaniach, podobnie jak w licznych szkicach przygotowawczych, Wróblewski odgrywa niekończący się moment przejścia od jednego paradygmatu suwerenności do innego, w którym ciało staje się nowym rodzajem podmiotu politycznego. Czekający na śmierć ulegli przemianie z jednostek w archetypy: Stara Żydówka, Matka, Ojciec, Dziecko, Przedsiębiorca, Robotnik, Powstaniec ${ }^{11}$.

To zaproponowane przez Banai rozpatrywanie ciała jako miejsca traumy wymusza bardziej wnikliwe zagłębienie się $\mathrm{w}$ materiały archiwalne pozostawione po Wróblewskim, jak i ponowne postawienie problemu badawczego - jak traumę rozumiał, przedstawiał/ reprezentował sam artysta? Banai nie komentuje tej koncepcji tylko w odniesieniu do śmierci ojca malarza. Wiąże ją przede wszystkim z cyklem Rozstrzelań, omawiając na ich przykładzie politykę śmierci, prawo i estetykę przedstawień. Tymczasem Wróblewski poprzez obrazy wojenne, a zwłaszcza ukazanie w nich metaforycznych przemian, jakim podlega ciało ludzkie skazane na śmierć, chciał pokazać sztukę jako jedyne suwerenne miejsce, w którym zakaz przedstawiania tabu może zostać przekroczony.

W takim też kontekście chciałabym spojrzeć na obraz Rewizja Aresztowanie, po pierwsze jako na moment uobecniania traumy, po drugie potraktować to przedstawienie jako zaprzeczenie obrazu śmierci (paradoks przedstawienia), a także zastanowić się nad jego możliwą korespondencją z cyklem Rozstrzelań, kontynuując zaproponowaną przez Banai koncepcję ciała jako miejsca traumy.

\footnotetext{
${ }^{11}$ Ibidem, s. 230-231.
} 


\section{Ciało jako miejsce traumy}

\section{Piotr Piotrowski w Znaczeniach modernizmu notował:}

Wojna, horror, trauma... Jacques Lacan pisał, że "trauma" - podstawowa kategoria określania rzeczywistości w kontekście psychoanalizy - określana jest jako chybione spotkanie z realnością. Praktyka terapeutyczna więc nie może się opierać na przedstawianiu rzeczywistości, lecz na powtarzaniu. [...] Zbliżenie się do rzeczywistości musi się dokonać poza konwencją, niejako na zasadzie bezpośredniej repetycji ${ }^{12}$.

Przywołany fragment $\mathrm{z}$ rozdziału Wojna $i$ obraz poprzedza w książce Piotrowskiego rozważania o twórczości Andrzeja Wróblewskiego i jej istocie, której autor dopatruje się właśnie we wspomnianym powtórzeniu. Czyni je kategorią interpretacyjną, według której stara się odczytać wielokrotnie już wspominany cykl Rozstrzelań. Badacz zwraca uwagę - za Andrzejem Kostołowskim - iż sztukę Wróblewskiego należy rozpatrywać konstelacyjnie: mając na uwadze „Wrażliwość i zaangażowanie artysty w problematykę społeczną" i jego zdolność do formułowania krytycznych tez dotyczących rzeczywistości oraz wpływ życia osobistego na jego działalność twórczą $^{13}$. Opowiadanie o rzeczywistości poza obowiązującą konwencją i trwanie w przeszłości to cechy bliskie twórczości Wróblewskiego.

Autorzy - m.in. wspomniany Andrzej Kostołowski czy Tomas Venclova - w odtwarzaniu życiorysu artysty koncentrowali się głównie na roli matki Krystyny Wróblewskiej, przygotowującej syna do pracy plastyka, skupiali się także na znaczeniu sztuki autora Nieba nad górami w historii polskiego i zagranicznego malarstwa. Jednak doświadczenie chłopca, który w 1941 roku był świadkiem śmierci własnego ojca, pozostawało jedynie dość lapidarnie wspominane w tych rejestrach.

Intuicja Piotrowskiego, upatrującego właśnie w przeżyciach z okresu dorastania silnego wpływu na całą późniejszą twórczość artysty, zdaje się jednak istotna w kontekście myślenia o „wileńskich" obrazach Wróblewskiego jako przestrzeni pamięci narracyjnej, świadectwa i przejawu realizmu traumatycznego.

W 1953 roku, dwanaście lat po śmierci ojca, Wróblewski namalował obraz olejny Okupacja, który w powszechnej recepcji zapisał się

12 P. Piотrowski: Znaczenia modernizmu. W stronę historii sztuki polskiej po 1945 roku. Poznań 1999, s. 10.

13 Ibidem, s. 13. 
jako Rewizja - Aresztowanie, dlatego też ten tytuł stosuję w niniejszej interpretacji ${ }^{14}$. Zostały na nim wyraźnie wyodrębnione dwie części, dwie strony tragicznego zdarzenia, przedstawiające uczestników i świadków. Po lewej stronie pola obrazowego malarz umieścił żołnierzy, ubranych $\mathrm{w}$ ciemnozielone, ciemnobrunatne mundury, którzy z fizyczną siłą i złością pojmali dojrzałego mężczyznę. Po prawej stronie dziecko, młoda kobieta i starzec przedstawieni są statycznie, tragicznie bezbronni. To obraz rozbijanej rodziny. Motyw rozczłonkowania, rozdzielenia i podziału, tak silnie obecny w całej dojrzałej twórczości artysty z lat 40. XX wieku, powraca również i w tym przedstawieniu. $W$ postaci małego chłopca wielu interpretatorów doszukiwało się alter ego samego Wróblewskiego. Ten trop, choć pozornie dość niepewny i dyskusyjny, w perspektywie traumy rodzinnej wydawać się może jednak znaczący.

Postaci przedstawione po lewej stronie zostały ujęte w ruchu, $\mathrm{w}$ procesie sugerującym gwałtowne wycofanie - najpierw wycofanie się (wycofanie kogoś) z pomieszczenia, potem z życia rodziny. To jakby przynaglenie do zapomnienia, jego przymus. Inaczej niż w przypadku drugiej strony, niejako „skazanej na pamięćc o opuszczającym. Gest rozdzielenia, jaki na płaszczyźnie płótna zastosował Wróblewski, zdaje się mieć także szersze znaczenie. Artysta nie tylko dokonał tu mechanicznego podziału pola obrazowego, ale nadał mu symboliczne znaczenie - pamięć o zranieniu i krzywdzie ma należeć do kilku pokoleń, które ocalały - pokolenia dziadków, rodziców i dzieci.

$\mathrm{Na}$ obrazie intrygują dwie postaci: dorosłego mężczyzny wyprowadzanego przez żołnierzy z mieszkania oraz małego chłopca znajdującego się $\mathrm{w}$ centrum przedstawienia, tuż przy ścianie, w łóżeczku. Mężczyzna jako jedyna postać na obrazie nie ma butów, jego nagie stopy korespondują w sposób bezpośredni z postaciami z cyklu Rozstrzelań. Podobnie jak one, mężczyzna ubrany jest w spodnie do kostek, spod których wystają jego gołe nogi. Uwidaczniają się tu bezpośrednie analogie $\mathrm{z}$ Rozstrzelaniem surrealistycznym oraz z Rozstrzelaniem VII, na których obok niebieskich postaci pojawiają się mężczyźni ubrani $\mathrm{w}$ kolorowe stroje $\mathrm{z}$ odsłoniętymi nogami, których nie pokrywa jeszcze niebieska, śmiercionośna barwa, idiomatyczna w malarstwie Wróblewskiego. Wyjątkiem jest odwrócona i pomniejszona postać z Rozstrzelania surrealistycznego, namalowana

${ }^{14}$ W katalogu Andrzej Wróblewski. Red. Z. GoŁubIEw. Warszawa: Galeria Sztuki Współczesnej Zachęta, Muzeum Narodowe w Krakowie, Fundacja Instytut Promocji Sztuki, 1998, s. 101 pojawia się informacja o jeszcze dwóch innych tytułach obrazu - Okupacja (tytuł autorski) i Rewizja. 
w całości sinoniebieską farbą, z wyjątkiem stóp, które zachowują cielistą barwę.

Rewizja - Aresztowanie to jeden z tych obrazów, w którym pozornie spełnia się założenie Banai o opóźnianiu przez Wróblewskiego przedstawienia samego momentu śmierci. Tymczasem zdaje się, że artysta potraktował wileńskie mieszkanie jako przestrzeń wypełnioną artefaktami traumy. Świadczyłby o tym nie tylko sposób przedstawienia mężczyzny z odkrytymi stopami, ale też i pozostająca $\mathrm{w}$ tle obrazu brunatna marynarka, wyrzucona podczas rewizji mieszkania na środek pokoju wraz z innymi rzeczami ukrytymi wcześniej w szafie. Porzucona marynarka odsyła do przedstawień wojennych, w których symbolizowała pokawałkowane ciała postaci, a w ostateczności również i śmierć.

W katalogu prac Wróblewskiego redagowanym przez Zofię Gołubiew obok obrazu Rewizja - Aresztowanie, a dokładniej na karcie go poprzedzającej, został przedrukowany obraz Rewizja - aresztowanie z 1952 roku. Przedstawia on starszego mężczyznę, ubranego w kaszkiet, dłuższy płaszcz, granatowe spodnie i czarne buty. W ręce trzyma on prawdopodobnie broń, którą mierzy przed siebie. Jego wzrok skoncentrowany jest wyraźnie na jakimś określonym miejscu, punkcie, którego odbiorca nie widzi. Mężczyzna znajduje się $\mathrm{w}$ pomieszczeniu, prawdopodobnie $\mathrm{w}$ przedsionku lub pokoju, na podłodze leżą w nieładzie, jakby po rewizji, rozrzucone książki, gazety. Obraz ten funkcjonował także pod innym tytułem: Aresztowanie komunisty, na jego odwrocie znajdował się zaś Model z obraczką. Przywołuję to dzieło z racji jego estetycznego podobieństwa do Rewizji - Aresztowania malowanego w latach 1952-1953. Tożsame miejsce, zbliżona poetyka przedstawienia, charakterystyczna brunatna i ciemnozielona kolorystyka każą przypuszczać, że to praca wstępna do tak zwanej rewizji ostatecznej.

Katalog ukrytych artefaktów traumy w obu obrazach nie kończy się jednak na wspominanych tu zależnościach i korespondencjach intersemiotycznych. Kontekstem dla tych przedstawień jest także historia płótna zatytułowanego Portret $z$ wnętrzem, który uchodził za dzieło zagubione. Konserwatorka sztuki Regina Kozik, pracując nad Pejzażem górskim, odsłoniła znajdujące się pod powierzchnią zapomniane dzieło Wróblewskiego ${ }^{15}$. W studium tym artysta przedstawił postać dojrzałego mężczyzny o dość silnej sylwetce, ubranego

${ }^{15}$ R. Koziк: Odnalezienie zaginionego obrazu autorstwa Andrzeja Wróblewskiego pod tytułem "Portret z wnętrzem" podczas prac konserwatorskich przy obrazie „Pejzaż górski”. „Ochrona Zabytków” 2012, nr 3-4, s. 53-58. 
w czarną czapkę, czarną marynarkę, brązowe spodnie i ciemne wysokie buty. Mężczyzna stoi przy drzwiach, chwytając za klamkę, jakby został uchwycony tuż przed wyjściem. W tle wpółotwarta szafa, w której wiszą ubrania, widać ciemnozielony, długi płaszcz, wszystko jeszcze pozostaje na swoim miejscu, nieporuszone. Nasuwają się skojarzenia z obrazem rewizyjnym: podobnie wyglądające drzwi, pojawiająca się w tle otwarta szafa, kaszkiet i marynarka na ciele mężczyzny pozwalają przypuszczać, że Wróblewski stworzył kilka sekwencji obrazów zlokalizowanych właśnie w tej symbolicznej, interiorycznej (czy domowej?) przestrzeni.

Zestawienie tych trzech płócien pozwala dostrzec odmienne stany, w jakich tworzył Wróblewski. Portret $z$ wnętrzem to obraz domu i ojca sprzed doświadczenia traumy; wiąże się z względnym poczuciem bezpieczeństwa, co potwierdza wykorzystanie ciepłych barw oraz pełny ubiór mężczyzny. Rewizja - Aresztowanie (Okupacja) i Rewizja aresztowanie (Aresztowanie komunisty; stosuję tu zapis tytułu za katalogiem wystawy pod redakcją Z. Gołubiew) namalowane są natomiast z perspektywy człowieka już uwikłanego w traumę rzeczywistości.

Mogłoby się więc wydawać, że obraz Rewizja - Aresztowanie jest klarowny i historycznie jednoznaczny, stanowi dokładne odtworzenie zdarzeń z przeszłości wileńskiej. Tymczasem wspomniana wcześniej postać małego chłopca w łóżeczku, usytuowanego centralnie, choć jakby w cieniu, w głębi obrazu, niepokoi odbiorcę, zaburza harmonię przedstawienia. Wróblewski w chwili śmierci ojca miał czternaście lat, jego brat Jerzy był o rok starszy od artysty. Niemożliwe więc, by przedstawiał on samego siebie. Metaforyczna wyobraźnia malarza, której dał wyraz w wielu swoich wcześniejszych obrazach, każe jednak zapytać o to, jak Wróblewski pamięta tamto zdarzenie.

W katalogu dzieł artysty, opracowanym przez Zofię Gołubiew, w metryce tego obrazu znaleźć można krótki opis:

Reminiscencja przeżyć okupacyjnych artysty; rewizji gestapo, podczas której zmarł na atak serca jego ojciec, Bronisław Wróblewski. Sportretowani: narzeczona, Teresa Reutt [...] i jej ojciec. Autorski tytuł: Okupacja. Wróblewski zaczął malować obraz 10 listopada 1952. Pracę kontynuował: 22-25 grudnia 1952; następnie 3-7, 9-15 lutego, 4, 20, 21 marca $1953^{16}$.

Rewizja - Aresztowanie jest dziełem, w które od początku zostało wpisane powtórzenie - zarówno semantyczne, tytułowe jako

${ }^{16}$ Andrzej Wróblewski. Red. Z. GoŁUbiew..., s. 101. 
re-wizja, zakładające powtórną wizję, jak i powtórzenie wskazujące na istotę traumy. Wróblewski dokonał tu niezwykle ważnego i przewrotnego gestu - zmiany perspektywy doświadczającego. Nie patrzy już/ jeszcze jak dorosły, dwudziestosześciolatek, nie wspomina też przeżyć czternastolatka, ale w centrum obrazu umieszcza dziecko, małego chłopca, niemego świadka historii. Być może stara się odtworzyć owo graniczne doświadczenie poprzez metaforę dziecka, które nie jest w stanie o nim opowiedzieć, dla którego język staje się zrozumiały, ale nie może być jeszcze narzędziem narracji, dziecka, uwikłanego w tragiczny los, które dostrzega więcej, i wreszcie dziecka, z którego się nie wyrasta, z emocjonalności, od której nie sposób uciec.

Dziecięca perspektywa na obrazie Rewizja - Aresztowanie nie pozostaje w żaden sposób beztroska. Najbardziej przejmująca wydaje się samotność chłopca, pozbawionego bezpośredniej opieki rodziców. To istotny punkt obrazu, z powodu którego warto zapytać o dwa przeciwstawne rozumienia traumy: tę, która dotyka jednostkę, osobę, grupę bezpośrednio i wydarzenie traumatyzujące, któremu mogą podlegać też osoby spoza doświadczenia. Jednocześnie uderza bliskość traumy i samotności. W tym pograniczu znaczeń mieściłaby się bowiem sztuka Wróblewskiego.

Warto w tym miejscu zwrócić uwagę na jeszcze jeden szczegół obrazu, dość rzadko interpretowany - a mianowicie jego tło, które stanowi ściana pokoju. Przedstawiona dwubarwnie od góry ocieplona biel, lekka szarość przechodząca w połowie w kolor niebieskoszary, spopielony zastosowana została przez Wróblewskiego nie bez znaczenia w pobliżu dziecka.

$\mathrm{Na}$ ile więc obraz ten jest powtórzeniem własnej historii, na ile należy go czytać jako metonimię polsko-wileńskiego pogranicza, a $\mathrm{w}$ jakim stopniu pozostaje wyłącznie artystyczną reprezentacją czasu wojny? Opisując to przedstawienie Wróblewskiego, warto zastanowić się nad kategorią świadka śmierci, świadka Zagłady. Obraz należy czytać więc nie tylko jako historię prywatną, ale jako egzemplifikację pokoleniowego doświadczenia obciążonego tragedią utraty. Być może właśnie rozszerzenie pola semantycznego tego przedstawienia o kategorie pokolenia było intencją artysty, nadającego swojemu ojcu cechy postaci rozstrzelanej ${ }^{17}$. Tych poziomów

${ }^{17}$ Figura świadka, tak silnie dziś obecna w badaniach historycznych, literaturoznawczych, z zakresu historii sztuki, za sprawą Raula Hilberga, Jana Błońskiego, Jana Tomasza Grossa, Czesława Miłosza, Tadeusza Różewicza, Zofii Nałkowskiej, Tadeusza Borowskiego, a także wielu innych autorów i badaczy, których nie sposób tu przywołać, w kontekście twórczości Andrzeja 
świadczenia - świadczenia sobą i świadczenia o pokoleniowym przeżyciu granicznym - jest, jak się wydaje, wiele. Na obrazie Wróblewskiego spotykają się liczne koncepcje bycia świadkiem.

Luiza Nader w książce Afekt Strzemińskiego. "Teoria widzenia”, rysunki wojenne, Pamięci przyjaciót - Żydów zwraca natomiast uwagę na problem materialności traumy:

Andrzej Wróblewski, tworzący [...] serię Rozstrzelań, wykorzystał do swych obrazów m.in. zdjęcia egzekucji ludności cywilnej Bydgoszczy. Tym samym chciał pokazać moment, kiedy rozgrywa się okrucieństwo, a zarazem rozpada się podmiotowość, następuje kres wszystkich relacji, człowiek umiera sam, w poniżeniu i wstydzie ${ }^{18}$.

Ta sytuacja $\mathrm{w}$ pewnym stopniu przypomina afektywny wymiar sztuki Władysława Strzemińskiego, o czym szczegółowo pisze badaczka. Artysta wykorzystał fotografie wojenne do własnych kolaży, w których znaczącym przekształceniom uległy pierwotne wizerunki ofiar $^{19}$. Podobnie Wróblewski, choć w zupełnie odmiennym stopniu i charakterze, posłużył się fotografiami jako pierwowzorami swoich prac. Wydobył on ze zdjęć konkretne twarze i postaci, by oddać ich lęk, wyrażony $\mathrm{w}$ formie ciała i pozwolił widzowi wniknąć $\mathrm{w}$ tę reprezentację $e^{20}$.

Być może z tego powodu Rewizję - Aresztowanie można czytać jako obraz poruszający kwestię utożsamienia artysty z traumą żydowską. Zaproponowany przez niego tryb mówienia o traumie oraz sposób jej wizualnego przeżywania pozwala potraktować dzieła malarskie jako formę narracji o Zagładzie. Obraz Andrzeja Wróblewskiego uświadamia, jak wiele szyfrów kryje się w twórczości tego osamotnionego artysty. To - jak się zdaje - miał na myśli Andrzej Kostołowski, kiedy wspominał:

Wróblewskiego domaga się osobnego artykułu lub szerszej publikacji. Warto skonfrontować doświadczenie wileńskie autora ze spostrzeżeniami odnośnie do obserwatora uczestniczącego, a później także świadka na wystawie. Por. numer tematyczny Ustanawianie świadka. „Teksty Drugie” 2018, nr 3. Tu zwłaszcza teksty: E. JANICKIEJ: Obserwatorzy uczestniczacy zamiast świadków i rama zamiast obrzeży. O nowe kategorie opisu polskiego kontekstu Zagłady oraz M. KовıеLsкA: Świadek na wystawie. Świadectwa w nowych muzeach historycznych.

${ }^{18}$ L. NADER: Afekt Strzemińskiego. "Teoria widzenia”, rysunki wojenne, Pamięci przyjaciót - Żydów. Warszawa 2018, s. 302-303.

19 Ibidem, s. 303.

${ }^{20}$ Por. I. LubA, E.P. Wawer: Władysław Strzemiński - zawsze w awangardzie. Rekonstrukcja nieznanej biografii 1893-1917. Łódź 2017. 
Każde dzieło Wróblewskiego jest organicznie związane z wydarzeniami, które towarzyszyły jego życiu. - Twórczość jego to nieustanny zapis, szyfr pełen symboliki i ukrytych znaczeń, mówiący o przeżyciach i pasjach Wróblewskiego więcej niż jakiekolwiek suche analizy ścisłej biografiii ${ }^{21}$.

Konsekwencją traumy dzieciństwa było powtarzanie własnej śmierci przez Wróblewskiego. Artysta wpisywał samego siebie w ciąg: świadomości - śmierci - nieświadomości, dlatego opublikowane w Unikaniu stanów pośrednich autotanatografie Wróblewskiego sygnalizują potrzebę szerszego omówienia prac artysty w kontekście antropologicznych i filozoficznych koncepcji śmierci. Jedną z takich prób podjął Wojciech Szymański, który postawił hipotezę, iż: „Wróblewski przeżywa [...] rozstrzelanie, ale zarazem, dzięki Rozstrzelaniom, które w kontekście uwag o romantycznej, rozpaczającej podmiotowości artysty są autoportretem - czuje, że co dzień umiera"'22.

\section{Paradygmat samotności. Pamiętnik samobójcy}

Trauma dzieciństwa sprawiła, że Wróblewski izolował się od społeczeństwa, w dorosłym już życiu nawiedzały go myśli samobójcze. Obrazy artysty przepełnione są samotnością: doświadczaną podczas oglądania nieba, samotnością kierowcy autobusu i tramwaju, samotnością architektury wznoszonej z geometrycznych brył, samotnością górskiego wędrowca zanurzoną $\mathrm{w}$ niebieskich reminiscencjach czy samotnością natury: opuszczonych drzew, porzuconych koni, pozostawionych przedmiotów martwych. Ale jest jeszcze autoidentyfikacyjna samotność postaci, tak wyraźnie oddawana w portretach i autoportretach, na których stopniowo znika perspektywa patrzenia wprost, sygnał oddalania się artysty od życia.

Poczucie ciągłego wyobcowania, jakie towarzyszyło Wróblewskiemu od momentu tragicznej śmierci ojca, oraz poczucie niemożności stania się tak spełnionym życiowo jak zajmujący się prawem brat

${ }^{21}$ A. Kosтоєowsкi: O postawie i zaangażowaniu społecznym Andrzeja Wróblewskiego. W: Andrzej Wróblewski 1927-1957. Katalog wystawy w 10. rocznice śmierci. Poznań 1967, s. 18. Cyt. za: W. Baraniewski: Pamięć obrazów / Obrazy pamięci. W: Perspektywa wieku dojrzewania. Szapocznikow - Wróblewski - Wajda. Red. A. Rottenberg. Katowice 2018, s. 188.

${ }^{22}$ W. Szyмański: "Obraz tym się różni od pilnika, że jest w użyciu wszechstronniejszy"..., s. 121. 
artysty Jerzy, przyczyniły się do podjęcia kilku prób samobójczych. $\mathrm{Z}$ tego czasu zachował się Pamiętnik samobójcy, w którym Wróblewski pisał:

Nieznośny był dom! Nikt mnie tam nie podtrzymywał i ponieważ sam nie mogłem czy nie umiałem żyć - więc odbiorę sobie życie; bo wtedy dopiero zobaczą, że brak jest mnie, i że robili mi krzywdę żyjąc mimo mnie [...]. Ludzie byli uprzedzająco uprzejmi, bo zasłaniała mnie Matka. Ja nigdy nie będę zdolny, aby samodzielnie zdobyć ich szacunek, a Matka to potrafi...23

[...] wychyliłem głowę przez wyszczerbione okno. Patrzyłem obojętnie w prawo, nad szarą naszą ulicą z samotniczymi domami, i dalej, nad dachami; aż po najdalsze wyniosłe bloki, za którymi był, zdaje się dworzec. [...] Miasto było samotne i ospałe jak przedtem $^{24}$.

Wydawać by się mogło, że Pamiętnik samobójcy, pisany częściowo po latach, będzie retrospektywny, zdystansowany wobec minionych zdarzeń, że będzie uniwersalizował doświadczenia życiowe Wróblewskiego. Tymczasem czyta się go w pewnej konwencji, zauważając celowe rozproszenie, brak logiki czy współwynikania faktów. W pamiętniku odczuwa się paradoksalną wolność artysty, zmagającego się z własnym losem, zaprzeczającego przed samym sobą konkretnej przeszłości. To zmaganie malarza $\mathrm{z}$ formą przypomina próby wielu autorów, którzy po Zagładzie i po wojnie próbowali znaleźć odpowiedni gatunek literacki dla opisania własnych doświadczeń granicznych.

Dla Wróblewskiego nie tyle Zagłada, ile wojna, nie tyle pamięć naoczna, ile wspomnienia, nie tylko prywatność losu, ale i powidoki wojny wpłynęły na doświadczanie życia z piętnem traumy. Dominantą przywołanych powyżej fragmentów pozostaje bowiem imperatyw samozniszczenia, wynikający z wszechobecnej pustki. Czasy szkolnego, a potem studenckiego zaangażowania $\mathrm{w}$ działalność grupy artystycznej, aktywność na rzecz wspólnoty, minęły bezpowrotnie, pozbawiając artystę utopijnej, społecznej ochrony. Samotność, nagle ujawniona i nazwana, wydawała się artystyczną powinnością, gestem wewnętrznym i otwarciem możliwości dla nowej powojennej estetyki. Ale przede wszystkim była tragiczna, bo wynikająca z poczucia nieodwracalnej traumy.

23 A. Wróblewski: Pamiętnik samobójcy. W: Unikanie stanów pośrednich. Andrzej Wróblewski (1927-1957)..., s. 140.

${ }^{24}$ Ibidem, s. 142-143. 
W Pamiętniku samobójcy pojawia się, zapewne celowe, nawiązanie do twórczości Juliana Tuwima. Może ono świadczyć o artystycznym pokrewieństwie malarza z samotnością odczuwaną przez poetę. Wróblewski wspomina bowiem fragment utworu Tuwima, w dość specyficznym, a zarazem symbolicznym miejscu, jakim były ruiny budowli w Częstochowie:

[...] wysiadłem w Częstochowie z niewyraźnym ciążeniem ku odosobnionym ruinom. I tu, w Częstochowie, zginęła moja myśl samobójcza w familiarnym spokoju letniego popołudnia na przedmieściach. Roztkliwiłem się, rozlałem w powietrzu. Każdy zna obraz małomiasteczkowej ulicy niedzielnej z tym specyficznym sumowaniem głupich detali w pełną nastroju całość: drzewo, jakiś gramofon, pies, szewc przed warsztatem ze stateczną żoną, auto $\mathrm{w}$ charakterze przedmiotu podziwianego i piegowaty facet na rowerze $w$ tymże charakterze; zakochane pary, zapach powietrza, dal słupów telegraficznych i ogródki, za płotkami z ławeczkami lub w skrzynkach pod oknami „całujemy w główki cudze dziatki / i podlewamy w oknach kwiatki" (Julian Tuwim) ${ }^{25}$.

Ten ostatni fragment pochodzi z wiersza Tuwima Staruszkowie z tomu Czyhanie na Boga. Utwór ten w pełnym kształcie brzmi tak:

Patrzymy sobie na ulice

Przez wpółrozwarte okiennice

W czółka całujem cudze dziadki

I podlewamy w oknach kwiatki

Żyjemy sobie jak Bóg zdarzy

Zrywamy kartki z kalendarzy ${ }^{26}$

Wróblewski jest subtelnym, a zarazem detalicznym czytelnikiem poezji. Bliscy byli mu Louis Aragon, Federico Garcia Lorca i Tadeusz Różewicz, a więc poeci zmagający się z wojennym losem, próbujący na nowo zapisać świat, odbudować język, przywrócić znaczenie dawnej metaforze. Często okaleczeni psychicznie, wykluczeni, osobni. Ale przede wszystkim podobnie samotni wobec swoich traum - Aragon słyszący nieustannie głosy zabitych, Lorca tworzący w przededniu hiszpańskiej wojny domowej, Różewicz zaś zmagający się z ocaleniem.

25 Ibidem, s. 156.

${ }^{26}$ J. Tuwim: Staruszkowie. W: IDEm: Wiersze wybrane. Oprac. M. GŁowiński. Wrocław-Warszawa-Kraków-Gdańsk-Łódź 1986, s. 11. 
Dlaczego jednak w tym szczególnym momencie życia artysty pojawia się Tuwim? Może dlatego, że poezja była dla niego przestrzenią wyrażania samotności, nieustannie odczuwanej przez autora samotności wielu istnień - staruszków, kobiet, dzieci, zwierząt. Może też z tego powodu, że poetycka samotność Tuwima wiązała się podobnie jak w przypadku Wróblewskiego z indywidualnym poczuciem czasu. Tak dzieje się $\mathrm{w}$ przywołanym wierszu, kiedy poeta biegnie do starości, która tylko pozornie łączy się z upragnionym odpoczynkiem, spokojem, beztroską. Biegnie do starości samotnej.

W Tuwimowskim kontekście szczególnie ważne pozostają także żydowskie reminiscencje zapisane w pamiętniku artysty:

Znajome ruiny nieznanego miasta. To w Łodzi znalazłem bezcenną bibliotekę hebrajską, nikczemnie rozrzuconą po rumowiskach piwnicy. Hieroglify tytułów i liczne pieczątki-nalepki zapobiegliwej biurokracji czcigodnych instytucji. Świat wchałaniający, piwniczny, zamykający widza w ciemni faustowskiego gabinetu, w ciasnym wnętrzu ożywionym pochyloną, niewidzącą głową uczonego. Kiedy z trudem wyrwałem się z dusznej atmosfery, szukałem zgorzkniałą wolą miejsca wiecznego spoczynku² ${ }^{27}$.

Spotkanie z hebrajską biblioteką, a więc spotkanie z językiem, pismem i kulturą, Wróblewski przeżywa niemal psychosomatycznie. To nie tylko bowiem sensualne doświadczenie dotyku książki, ale również odczucie lęku przeszłości, zejście w głąb, piekielne zstąpienie. Nasilająca się w nim duszność, poczucie zamknięcia, wzmagający się strach przed byciem pod powierzchnią ziemi, symboliczna piwnica, wszystko to przywołuje prawdę wojny i dawnego getta oraz postaci ukrywających się Żydów. O takim traumatycznym doświadczeniu opowiada Michał Głowiński w Czarnych sezonach w rozdziale Piwnica. Sytuacja podziemia całkowicie zmieniła życie niespełna wówczas ośmioletniego chłopca:

[...] moja rodzina, i spora liczba sąsiadów (może wszyscy?) skryła się $\mathrm{w}$ jednej z piwnic, najdalej położonej od wejścia, aczkolwiek z pewnością niezbyt dobrze zakonspirowanej. $\mathrm{O}$ ile pamiętam, dozorca zamknął ją od zewnątrz. [...] Był ścisk, sklepienie znajdowało się tak nisko, że nie sposób było stać. Wiedziałem już dobrze, o co tutaj chodzi, czego chcemy uniknąć, ukrywając się w miejscu, które nie nadaje się do życia. [...] Było ciemno, obowiązywało absolutne milczenie, spoza tych ścian nie miała prawa się wydobyć

\footnotetext{
${ }^{27}$ Ibidem, s. 153-154.
} 
żadna oznaka życia. [...] przebywanie w piwnicy trwa we mnie do dzisiaj, nie skończyło się wraz z otworzeniem drzwi - i to nie tylko dlatego, że z chwilą, w której skończyło się to konkretne zagrożenie, nie przeminęło niebezpieczeństwo. [...] Było to pierwsze zetknięcie z zamknięciem tego rodzaju².

Po latach powracają symptomy towarzyszące ukrywającemu się światu żydowskiemu. Wspomniane przez Głowińskiego tragiczne continuum Wróblewski odnajduje w porzuceniu, zapomnieniu i wyparciu kultury hebrajskiej. Dramatycznym tego przejawem pozostają opieczętowane publikacje, przywołujące skojarzenie ksiąg zakazanych, których nie należy ponownie otwierać. Podobnie jak w przypadku Głowińskiego, wyjście na powierzchnię nie przynosi też ulgi artyście, jedynym ratunkiem wydaje mu się kolejna próba samobójstwa. Wróblewski w Pamiętniku zapisuje: „I oto jestem i usiłuję się powiesić" ${ }^{29}$. Powodem odebrania sobie życia jest strach przed opóźniającą się śmiercią.

W Pamiętniku pojawia się jeszcze jeden fragment, silnie zmetaforyzowany, świadczący o pogrążeniu artysty w amoku samobójczych obsesji i myśli o ocaleniu. Z kolejnej próby ratuje go milicjant w cywilu:

Patrząc wstecz, spostrzegam drugą stronę medalu: jakiś porucznik-Żydek i paru młodych chłopców, którzy o mnie mówili: chyba Niemiec, kto jego wie!; śledztwo zaczęto znienacka od pytania, dlaczego mam krótkie włosy. Musiałem być niedawno ogolony (?) (obóz, ha, ha, ha). Głupstwa ${ }^{30}$.

Stany autodestrukcyjne Wróblewskiego były częstym źródłem zmąconych, pogranicznych myśli. W przytoczonym fragmencie znacząca pozostaje próba utożsamienia się artysty z żydowską traumą. $\mathrm{Na}$ ten proces mogą wskazywać: wątek niemiecki, ogolona głowa, przypomnienie obozu. Widać tutaj najmocniej stylistyczne, emocjonalne i tożsamościowe zagubienie Wróblewskiego, sytuującego się „pomiędzy”. Formuła entrée dotyczy właściwie całej historii traumy artysty postawionego pomiędzy dawnym życiem i teraźniejszością, historią i wspomnieniem, pamięcią i zapoznaniem, raną i zabliźnieniem, ocalonym i ocalałym, życiem i śmiercią, w ciągłej pokusie samobójstwa.

${ }^{28}$ M. GŁowiński: Czarne sezony. Kraków 2002, s. 19-20.

29 A. Wróblewski: Pamiętnik samobójcy..., s. 154.

${ }^{30}$ Ibidem. 
Rewizja zatem to nie tylko tytuł obrazu, nie tylko trop interpretacyjny. Za indywidualną rewizją kryje się także rozpoznanie sytuacji kraju, wciąż pogrążonego w milczeniu po Zagładzie. Rewizja - Aresztowanie to obraz ciągle aktualny jako akt zaświadczania o nowych formach mówienia o śmierci, o zmaganiu się z traumą śmierci. Rewizja to także metoda badania sztuki Andrzeja Wróblewskiego, poddawanej nieustannym rekonfiguracjom i odczytaniom. Z tego powodu w tytule artykułu zastosowałam koncept podwójnej liczby: pojedynczej i mnogiej - rewizja/e.

Dialektykę traumy Wróblewski wyrażał najpełniej w maksymie „pędu ku śmierci”. Czy oznaczał on ucieczkę od rzeczywistości, czy też wskazywał naturalne, choć hiperbolizowane przez artystę, koleje losu? A może był także sposobem na trwanie z ojcem, pozostawaniem wciąż w czasie wojny? Ta podwójność światów, jaką wywołała trauma dzieciństwa, towarzyszyła artyście do końca, skazując go na nieuleczalną melancholię:

Wagon był domem od wieków [...] nie wierzyłem w opuszczenie go. Wdychałem pełną piersią czar życia w mijaniu; bez bagażu spraw przeszłych i przyszłych, jakby wciąż między dwoma światami zawieszony w upajającej się próżni, skąd widać kalejdoskop życia miasta i świata. Widziałem - patrzyłem. [...] Melancholijnie sterczące wejście do schronu w kształcie betonowej wieżyczki pokazywało palcem w niebo, że i tam się coś dzieje; istotnie: strzelali, latali, chociaż już było po wojnie ${ }^{31}$.

\section{Bibliografia}

Andrzej Wróblewski. Oprac. A. Wojciechowsкi. Warszawa 1979.

Andrzej Wróblewski. Red. Z. GoŁubiew. Warszawa 1998.

Andrzej Wróblewski nieznany. Red. J. Michalski. Kraków 1993.

Antologia studiów nad traumą. Red. T. Łysak. Przeł. T. Bilczewski, K. Bojarska,

J. Burzyński, A. Kowalcze-Pawlik, A. Rejniak-Majewska. Kraków 2015.

Assmann A.: Przestrzenie pamięci. Formy i przemiany pamięci kulturowej. Tłum.

P. Przybyєa. W: Pamięć zbiorowa i kulturowa. Współczesna perspektywa niemiecka. Red. M. Saryusz-Wolska. Kraków 2009, s. 128-139.

Banai N.: Figuracja eksperymentalna w stanie wyjątkowym. W: Unikanie stanów pośrednich. Andrzej Wróblewski (1927-1957). Red. M. Zıó£коwsкA, W. GrzyвaєA. Warszawa 2014, s. 220-251.

${ }^{31}$ Ibidem, s. 148. 
Baraniewski W.: Pamięć obrazów / Obrazy pamięci. W: Perspektywa wieku dojrzewania. Szapocznikow - Wróblewski - Wajda. Red. A. Rottenberg. Katowice 2018, s. $188-211$.

Bojarska K.: Trauma. W: Modi memorandi. Leksykon kultury pamięci. Red. M. Saryusz-Wolska, R. Traba. Warszawa 2014, s. 501-506.

Borucki A.: Własna wojna Andrzeja Wróblewskiego 1927-1957. „Akcent” 1987, nr 1, s. $142-143$.

Foster H.: Powrót Realnego. Awangarda u schyłku XX wieku. Przeł. M. Borowski, M. Sugiera. Kraków 2012.

GŁowiŃski M.: Czarne sezony. Kraków 2002.

JANICKA E.: Obserwatorzy uczestniczacy zamiast świadków $i$ rama zamiast obrzeży. O nowe kategorie opisu polskiego kontekstu Zagłady. „Teksty Drugie” 2018, nr 3, s. 131-147.

JaRecka D.: Wewnętrzne organy kontroli. W: Ciała zdruzgotane, ciała oporne. Afektywne lektury XX wieku. Red. A. Lipszyc, M. Zaleski. Warszawa 2015, s. $128-147$.

Kobielska M.: Świadek na wystawie. Świadectwa w nowych muzeach historycznych. „Teksty Drugie” 2018, nr 3, s. 295-308.

Kostoєowsкi A.: O postawie i zaangażowaniu społecznym Andrzeja Wróblewskiego. W: Andrzej Wróblewski 1927-1957. Katalog wystawy w 10. rocznicé śmierci. Poznań 1967, s. 18.

Kozıк R.: Odnalezienie zaginionego obrazu autorstwa Andrzeja Wróblewskiego pod tytułem "Portret $z$ wnętrzem" podczas prac konserwatorskich przy obrazie "Pejzaż górski”. "Ochrona Zabytków” 2012, nr 3-4, s. 53-58.

Kronika wydarzeń. Andrzej Wróblewski kraj. Oprac. M. TarabuŁa. W: Andrzej Wróblewski nieznany. Red. J. Michalski. Kraków 1993, s. 261-308.

Luba I., Wawer E.P.: Władysław Strzemiński - zawsze w awangardzie. Rekonstrukcja nieznanej biografii 1893-1917. Łódź 2017.

Michalski J.: Chłopiec na żółtym tle. Teksty o Andrzeju Wróblewskim. Kraków 2009.

Modi memorandi. Leksykon kultury pamięci. Red. M. SAryusz-Wolska, R. Traba. Warszawa 2014.

Nader L.: Afekt Strzemińskiego. „Teoria widzenia”, rysunki wojenne, Pamięci przyjaciót - Żydów. Warszawa 2018.

Nowicka D.: Art-biografie Andrzeja Wróblewskiego. „Poznańskie Studia Polonistyczne. Seria Literacka" 2019, nr 35, s. 55-78.

Nowicka D.: Artysta i mit. Wokót „Treści uczuciowej rewolucji” Andrzeja Wróblewskiego. „Porównania” 2018, T. 23, nr 2, s. 259-278.

Nowicka D.: Błękitne, wewnętrzne [...] sa w wołaniu. Im-pasywne obrazy w poezji Juliana Kornhausera [Od Wróblewskiego: Niebo nad górami]. W: Rzeczy do nazwania. Wokół Kornhausera. Red. A. Gleń, J. Kornhauser. Poznań, s. 470-482.

Nowicka D.: "Styszę was głosy zabitych" - Andrzeja Wróblewskiego przypis do Louisa Aragona. "Narracje o Zagładzie” 2019, nr 5, s. 176-198.

Nowicka D.: Zasypia ryba. Autobiograficzne i zwierzęce niepokojenia w malarstwie Andrzeja Wróblewskiego. „Narracje o Zagładzie” 2017, nr 3, s. 217-232. 
Piotrowsкi P.: Znaczenia modernizmu. W stronę historii sztuki polskiej po 1945 roku. Poznań 1999.

Szymańsкi W.: "Obraz tym się różni od pilnika, że jest w użyciu wszechstronniejszy” lub Andrzej Wróblewski na nowo odczytany: notatki na marginesie "Unikania stanów pośrednich”. „Sztuka i Dokumentacja” 2014, nr 11, s. 115-124.

Tuwim J.: Wiersze wybrane. Oprac. M. GŁowiński. Wrocław-Warszawa-KrakówGdańsk-Łódź 1986.

Ubertowska A.: Holokaust. Auto(tanato)grafie. Warszawa 2014.

Unikanie stanów pośrednich. Andrzej Wróblewski (1927-1957). Red. M. ZıóєкошsкA, W. Grzyba£A. Warszawa 2014.

Wróblewski A.: Pamiętnik samobójcy. W: Unikanie stanów pośrednich. Andrzej Wróblewski (1927-1957). Red. M. ZıóєкоwSKA, W. GrzyвA£A. Warszawa 2014, s. $138-158$.

Daria Nowicka - doktorantka na Wydziale Filologii Polskiej i Klasycznej Uniwersytetu im. Adama Mickiewicza w Poznaniu. Laureatka II Nagrody im. Jana Józefa Lipskiego za pracę Jednokładne figury Eksterminacji. Pożydowskie doświadczenie Zagłady w twórczości Jerzego Ficowskiego i Władysława Strzemińskiego. Wśród jej zainteresowań znajdują się studia nad postpamięcią, poetyką i intertekstualnością obrazu (po)wojennego, a także reprezentacje Zagłady. Członkini Koła Miłośników Kultury i Literatury Żydowskiej Dabru Emet działającego na poznańskiej polonistyce.

e-mail: daria.nowicka@amu.edu.pl 
